\title{
The Relationship Between Interleukin-17 and Osteoporosis in Patients with Rheumatoid Arthritis
}

\author{
Romatoid Artrit Tanılı Hastalarda Interlökin-17 ile Osteoporoz Arasındaki Ilişki \\ (D) Sedef Akdeniz, (1) Olcay Akdeniz*, (1) Nurdan Sakallı**, (1) Gülcan Gürer, (D) Mevlüt Türe***, (D) Hilal Yeşil**** \\ Adnan Menderes University Faculty of Medicine, Department of Physical Medicine and Rehabilitation, Aydin, Turkey \\ ${ }^{*}$ Aydın Söke Fehime Kocagöz Hospital, Clinic of Orthopaedics and Traumatology, Aydın, Turkey \\ ${ }^{*}$ Adnan Menderes University Faculty of Medicine, Department of Biochemistry, Aydın, Turkey \\ ${ }^{* * *}$ Adnan Menderes University Faculty of Medicine, Department of Biostatistics, Aydin, Turkey

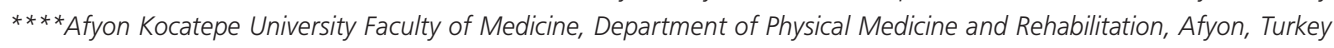

\section{Abstract}

Objective: In this study; it is aimed to compare interleukin-17 (IL-17) levels in rheumatoid arthritis (RA) and osteoporosis (OP) patients compared to healthy controls, and to determine the relationship between IL-17 and disease activity, functional status and presence of OP in RA.

Materials and Methods: Eighty five patients were classified in four groups. Group 1: RA + OP ( $n=21)$, group 2: RA ( $n=22$ ), group 3: 20 healthy volunteers, and group 4: OP ( $n=22)$. Demographical data, bone densitometry values, serum 25-hydroxy vitamin $D$ and IL-17 levels were recorded. The disease duration, medications, pain levels of the patients and the disease activities were noted, and the disease activities of patients were evaluated by the health assessment questionnaire.

Results: No difference was detected between IL-17 levels of patients with and without RA ( $p>0.05)$. Likewise, we could not establish a relationship between disease activity and IL-17 levels. However, IL-17 levels of RA patients with OP were significantly higher when compared with patients without OP. Rheumatoid factor and IL-17 levels were higher for RA patients with OP. While a significant, negative correlation was established between IL-17 and lumbar T-score with femoral bone mineral density, no correlation was detected between other variables in RA patients.

Conclusion: IL-17 levels are elevated in RA and OP. While there is no relationship between IL-17 and disease activity and functional status in RA; IL-17 levels are high in RA patients with OP.

Keywords: Interleukin-17, rheumatoid arthritis, osteoporosis

\section{Öz}

Amaç: Bu çalışmada; romatoid artrit (RA) ve osteoporoz (OP) hastalarında interlökin (IL)-17 düzeylerinin sağlıklı kontrollere göre karşılaştıııması ve RA da hastalık aktivitesi, fonksiyonel durum ve OP varlığının IL-17 ile arasındaki ilişkisinin belirlenmesi amaçlanmıştır.

Gereç ve Yöntem: Seksen beş hasta 4 grupta sınıflandırıldı. Grup 1: RA + OP (n=21), grup 2: RA (n=22), grup 3: 20 sağlıklı gönüllü, grup 4: OP ( $n=22)$. Demografik veriler, kemik dansitometresi değerleri, serum 25-hidroksi vitamin D ve IL-17 düzeyleri kaydedildi. Hastaların hastalık süreleri, ilaçları, ağrı düzeyleri ve hastalık aktiviteleri de kaydedildi ve hastalık aktiviteleri sağlık değerlendirme anketi ile değerlendirildi.

Bulgular: RA olan ve olmayan hastaların IL-17 düzeyleri arasında fark saptanmadı ( $p>0,05)$. Benzer şekilde, hastalık aktivitesi ile IL-17 düzeyleri arasında bir ilişki saptamadık. Bununla birlikte, OP'si olmayan hastalarla karşılaştııılığında, OP'li RA hastalarının IL-17 düzeyleri anlamlı olarak yüksek bulundu. OP'li RA hastalarında romatoid faktör ve IL-17 düzeyleri daha yüksekti. IL-17 ve lumbar T skoru ile femoral kemik mineral yoğunluğu arasında anlamlı, negatif korelasyon saptanırken, RA hastalarında diğer değişkenler arasında korelasyon saptanmadı.

Sonuç: RA ve OP'de IL-17 seviyeleri yüksektir. RA'da IL-17 ile hastalık aktivitesi ve fonksiyonel durum arasında ilişki saptanmaz iken, OP'si olan RA'lı hastalarda IL-17 düzeyleri yüksektir.

Anahtar kelimeler: Interlökin-17, romatoid artrit, osteoporoz

Address for Correspondence/Yazışma Adresi: Hilal Yeşil MD, Afyon Kocatepe University Faculty of Medicine, Department of Physical Medicine and Rehabilitation, Afyon, Turkey Phone: +90 5054423141 E-mail: dradanur@yahoo.com ORCID ID: orcid.org/0000-0002-8291-1515 Received/Geliş Tarihi: 08.04.2018 Accepted/Kabul Tarihi: 08.08.2018

${ }^{\circ}$ Copyright 2018 by the Turkish Osteoporosis Society

Turkish Journal of Osteoporosis published by Galenos Yayınevi. 


\section{Introduction}

Rheumatoid arthritis (RA) is a chronic immune-mediated inflammatory disease, characterised by marginal bone erosion and cartilage destruction of unknown aetiology due to synovial inflammation (1). The deformation on remodelled bones in RA causes not only bone erosion, but also development of systemic osteoporosis (OP). OP is one of the most common comorbidies encountered in RA. The risk of vertebral fracture regardless of bone mineral density and corticosteroid administration is increased in patients with RA (2). The fracture risk is 10\%$56 \%$ in RA, this percentage is higher in comparison to general population $(3,4)$. Thus, OP and associated fractures in RA patients lead to an impaired quality of life and an increased health expenditures (5).

Although there are several factors, which may cause OP in RA, the imbalance of inflammatory cytokines in receptor activator of nuclear factor kB (RANK)-RANK ligand (RANKL)osteoprotegerin (OGP) system is considered to be the most common reason (5). The principal cytokines that lead to increase in bone resorption are tumor necrosis factor (TNF), interleukin (IL)-1 and IL-6. The role of IL-17 in joint inflammation and damage has also been detected recently $(6,7)$. IL-17 is a recently defined cytokine family with its six members (8). IL-17A, IL-17B, IL-17C, IL-17D, IL-17E, and IL-17F belong to this cytokine group (9). IL-17 is mainly produced by so called T-helper (Th)-17 cells, which are actually CD4 + T cells (10). The primary function of Th-17 cells is to eliminate pathogens and to induce inflammation with IL-17. On the contrary to IL-17, IL-17 receptor may be produced everywhere. Therefore, many different cells may be targeted to IL-17 (11). Five receptors are defined for IL-17 so far [IL-17 receptor (IL-17 R) A, IL-17 RB, IL-17 RC, IL-17 RD, and IL-17 RE]. IL-17 RA binds IL-17A. The specifity between IL-17 and IL-17 R has not been clearly enlightened yet. However, it has been shown that IL-17 RA and IL-17 RC bind IL-17A and IL-17F $(12,13)$. In autoimmune diseases, IL-17 has a crucial role for osteoclast formation. The binding of IL-17 to its receptor activates nuclear factor-kB (NF-kB) and mitogen-activated protein kinase (MAPK). IL-17 is also required for activated clotting time (ACT)-1, which is the activator of NF-kB pathway. The studies regarding RA, have revealed that Th-17 cells not only provide production of RANKL but also ensure secretion of RANKL by stimulating osteoblasts and induce osteoclast differentiation (14). IL-17 plays a major role at the early onset and late progression phases in RA pathogenesis. It induces collagen destruction, decreases collagen synthesis in synovium and cartilage, and reduces bone formation by increasing bone destruction $(15,16)$. The inhibition of IL-17 may prevent joint inflammation and bone destruction. In this study, we aimed to evaluate the correlation between IL-17 level and OP in RA patients. We would like to show whether there exists a correlation between IL-17 levels, disease activities, and functional situations in RA patients.

\section{Materials and Methods}

\section{Patients}

This cross-sectional study comprised 85 patients who were visiting the outpatient rheumatic disease clinics of the physical medicine and rehabilitation department of our universities. The patients were divided into four groups. Group 1 was composed of 21 patients diagnosed with RA in accordance to 2010 criteria of the American College of Rheumatology (ACR) and who had OP according to the World Health Organisation. Group 2 was composed of 22 patients, who only had RA but did not suffer from OP. Group 3 was composed of 20 healthy volunteers who neither suffered from an autoimmune disease nor received concomitant treatment nor had OP. Group 4 was composed of 22 volunteers who neither suffered from an autoimmune disease nor received any concomitant treatment however had OP. The inclusion criteria were; an RA diagnosis according to the ACR criteria, the exclusion criteria were as follows: 1) RA patients who had secondary OP (patients with cancer, untreated thyroid and parathyroid diseases, end-stage renal disease, and hypogonadism), 2) metabolic bone disease, 3) primary bone tumour or bone metastasis, 4) osteomyelitis, 5) patients receiving anti-TNF therapy.

\section{Data Collection}

Patients' demographic data [age, sex, height, weight, body mass index (BDI), marital status, education] and clinical data (duration of the disease, medications used for treatment, duration of morning stiffness) were obtained from patient files and through face-to-face interviews. Smoking, alcohol consumption, fracture history, and family history for fracture were also noted. Bone densitometry values were evaluated with dual-energy X-ray absorptiometry (DEXA). Total lumbar (L2-4) measurement and femoral neck T scores were registered. The patients with $T$ score $\geq-1$ standard deviation (SD) were evaluated as normal; $T$ score between -1 and -2.5 as osteopenia; T score $\leq 2.5$ SD as OP; and those patients, who have one or more fragility fractures, were assessed as severe OP in accordance to World Health Organisation's evaluations. Blood serum 25-hydroxy vitamin D, parathyroid hormone, and calcium levels were assessed in the scope of laboratory analysis. Double antibody sandwich ELISA test was utilised for IL-17 analysis in all patients. (Sunred Biological Technology Human IL-17 Elisa Kit Catalogue no: 201-12-0143) At the end of study, absorbents were read at $450 \mathrm{~nm}$ wavelength, and results were given as $\mathrm{pg} / \mathrm{mL}$. The disease duration for RA, the medications used for RA, and the number of sensitive and swollen joints were noted. The pain levels of patients were evaluated by visual analogue scale (VAS); the disease activities by disease activity score (DAS) 28 score; and the functional situation by health assessment questionnaire (HAQ). The disease activities were determined in accordance to DAS 28 scores. The scores of DAS $28>5.1$ is evaluated as high; from 5.1 to 3.2 as average, and from 2.6 to 3.2 as low, and if it is <2.6, it was evaluated as in remission (17). 
Functional situations of patients were assessed in accordance to HAQ for disability index score. Score $<0.3$ is normal (18). Written informed consent was obtained from all patients. The study was approved by the Adnan Menderes University Hospital Ethics Committee (protocol no: 2015/750). Informed consent form was signed for all patients.

\section{Statistical Analysis}

SPSS for Windows 15.00 software package has been used for analyzing the data. The descriptive statistics for categorical variables were shown as \%, and chi-square tests were utilised for comparison in accordance to groups. The compatibility of continuous variables to normal distribution was analysed by Kolmogorov-Smirnov test. The descriptive statistics of normal distribution variables were shown by mean $\pm S D$, and t-tests were used for independent groups for the comparison in accordance to groups. The descriptive statistics of non-normal distribution variables were shown by median (25\%-75\%), and Mann-Whitney $U$ test was used for the comparison in accordance to the groups. Pearson correlation analysis was performed for determination of relation between continuous variables.

\section{Results}

The comparison of the characteristics of patients with arthritis and without arthritis is shown in Table 1. No significant correlation could be established among genders, ages, BMI, smoking and alcohol consumption, DEXA measurement scores, laboratory tests (25-hydroxy vitamin D, parathyroid hormone, calcium), and notably IL-17 ( $>>0.05)$. The comparison of nonRA patients with and without OP is shown in Table 1. Age, Lumbar $T$ score, lumbar bone mineral density (BMD), femoral $T$ score, and 25-hydroxy vitamin D levels were found significantly different from healthy individuals $(p=0.03, p<0.001, p<0.001$, $p=0.008$, and $p=0.005$, respectively). No correlation between other variables and OP was established $(p>0.05)$. For IL-17 levels, no differentiation was distinguished between the two

Table 1. Baseline demographic and clinical characteristics of the patients

\begin{tabular}{|c|c|c|c|c|c|c|}
\hline & $\begin{array}{l}\text { RA patients } \\
(n=43)\end{array}$ & $\begin{array}{l}\text { Non RA patients } \\
(n=42)\end{array}$ & $p^{*}$ & $\begin{array}{l}\text { Healty colunteers } \\
(n=20)\end{array}$ & $\begin{array}{l}\text { OP patients } \\
(n=22)\end{array}$ & $p^{* *}$ \\
\hline $\begin{array}{l}\text { Gender } \\
\text { (female, n, \%) }\end{array}$ & $37(84.1)$ & $37(90.2)$ & 0.60 & $19(95.0)$ & $19(86.4)$ & 0.61 \\
\hline Age (years, min-max) & $57(49.0-63.0)$ & $59(52.0-66.3)$ & 0.29 & $53.10 \pm 10.57$ & $62.45 \pm 8.65$ & 0.03 \\
\hline $\begin{array}{l}\text { BMI } \\
\left(\mathrm{kg} / \mathrm{m}^{2}, \text { min-max }\right)\end{array}$ & $30.4(26.1-33.8)$ & $29(25.9-36.0)$ & 0.89 & $32.22 \pm 7.38$ & $29.39 \pm 4.56$ & 0.15 \\
\hline Smoker (yes, n, \%) & $9(20.5)$ & $4(9.8 \%)$ & 0.28 & $2(10)$ & $2(9.1)$ & 1.00 \\
\hline Alcohol (yes, n, \%) & $0(0)$ & $2(4.9)$ & 0.23 & $1(5)$ & $1(4.5)$ & 1.00 \\
\hline Fracture (yes, n, \%) & $4(9.1)$ & $6(14.6)$ & 0.51 & $1(5)$ & $5(22.7)$ & 0.19 \\
\hline $\begin{array}{l}\text { Number of births } \\
\text { (n, min-max) }\end{array}$ & $2(2-3)$ & $2(2-3)$ & 0.44 & $2.0(2.0-3.0)$ & $2.5(1.7-4.0)$ & 0.77 \\
\hline $\begin{array}{l}\text { Age at menopause } \\
\text { (years, min-max) }\end{array}$ & $47(44-51)$ & $46(40-48)$ & 0.27 & $46.5(43.2-48.0)$ & $45.0(38.0-49.2)$ & 0.75 \\
\hline $\begin{array}{l}\text { Lumbar total T score } \\
\text { (min-max) }\end{array}$ & $-2.2[(-2.6)-(-1.4)]$ & $-2.0[(-2.7)-(-1.2)]$ & 0.71 & $-1.4[(-1.6)-(-0.3)]$ & $-2.6[(-3.1)-(-2.5)]$ & $<0.001$ \\
\hline $\begin{array}{l}\text { Lumbar BMD } \\
\left(\mathrm{g} / \mathrm{cm}^{2}, \text { min-max }\right)\end{array}$ & $0.816(0.764-0.905)$ & $0.817(0.717-0.891)$ & 0.78 & $0.89(0.87-1.00)$ & $0.73(0.65-0.77)$ & $<0.001$ \\
\hline $\begin{array}{l}\text { Femoral T score } \\
\text { (min-max) }\end{array}$ & $-1.2[(-2.0)-(-0.4)]$ & $-1.4[(-1.9)-(-0.7)]$ & 0.50 & $-0.9[(-1.5)-(-0.4)]$ & $-1.5[(-2.5)-(-1.1)]$ & 0.008 \\
\hline $\begin{array}{l}\text { Femoral BMD } \\
\left(\mathrm{g} / \mathrm{cm}^{2}, \text { mean } \pm \mathrm{SD}\right)\end{array}$ & $0.717 \pm 0.117$ & $0.714 \pm 0.128$ & 0.56 & $0.75 \pm 0.10$ & $0.67 \pm 0.13$ & 0.057 \\
\hline $\begin{array}{l}\text { 25-hydroxy vitamin D } \\
(\mathrm{ng} / \mathrm{mL} \text {, mean } \pm \mathrm{SD})\end{array}$ & $23.4 \pm 8.70$ & $20.9 \pm 10.09$ & 0.24 & $16.50 \pm 8.15$ & $25.06 \pm 10.11$ & 0.005 \\
\hline $\begin{array}{l}\text { Parathyroid hormone } \\
(\mathrm{pg} / \mathrm{mL} \text {, mean } \pm \text { SD) }\end{array}$ & $96.9 \pm 45.48$ & $92.63 \pm 36.59$ & 0.14 & $86.5(70.7-116.8)$ & $91.3(53.1-126.1)$ & 0.86 \\
\hline $\begin{array}{l}\text { Serum calcium } \\
(\mathrm{mmol} / \mathrm{L}, \text { mean } \pm \mathrm{SD})\end{array}$ & $9.3 \pm 0.43$ & $9.3 \pm 0.49$ & 0.12 & $9.39 \pm 0.55$ & $9.25 \pm 0.43$ & 0.35 \\
\hline $\begin{array}{l}\text { IL-17 } \\
(\mathrm{pg} / \mathrm{mL}, \text { min-max })\end{array}$ & $409.2(307.2-465.9)$ & $412.9(369.9-804.0)$ & 0.40 & $425.0(364.0-963.0)$ & 400.7 (369.5-729.6) & 0.55 \\
\hline \multicolumn{7}{|c|}{$\begin{array}{l}\text { BMD: Bone mineral density, BMI: Body mass index, IL-17: Interleukin-17, RA: Rheumatoid arthritis, OP: Osteoporosis, SD: Standard deviation, Min: Minimum, } \\
\text { Max: Maximum, *Differences between rheumatoid arthritis and non-rheumatoid arthritis patients, }{ }^{*} \text { Differences between healty volunteers and osteoporotic patients, } \\
\text { Independent samples t-test and Mann-Whitney U test used }\end{array}$} \\
\hline
\end{tabular}


groups. In comparison to the normal healthy volunteers the patients with OP were significantly younger although their weights and heights were significantly higher. The comparison of RA patients with and without OP is shown in Table 2. The height, menopausal age, lumbar T score, lumbar BMD, femoral T score, femur BMD and IL-17, RF levels were considered significantly high in patients with RA and $O P$, and in only RA patients $(p=0.035, p=0.012, p<0.001, p<0.001, p<0.001$, $p<0.001, p=0.027, p=0.010$, respectively). No significant correlation was found between the other variables $(p>0.05)$. According to this finding RA patients with OP were shorter, had earlier menopausal age, and their DEXA results were lower as expected. RF levels and IL-17 levels were higher for RA patients with OP. Correlation between IL-17 level with different variables in patients with RA is shown in Table 3. While a significant negative correlation was established between IL-17, lumbar $T$ score, and femoral BMD ( $p=0.045, p=0.044$, respectively), no correlation was detected between the other variables in RA patients $(p>0.05)$.

\section{Discussion}

In this study; we aimed to compare IL-17 levels in RA and OP patients compared to healthy controls, and to determine disease activity, functional status and relationship of OP with $\mathrm{IL}-17$ in RA, and we found no difference between IL-17 levels of patients with and without RA. Likewise, we could not establish a correlation between disease activity and IL-17 levels. In several studies, IL-17 levels in RA patients have been found to be elevated $(6,15,16,19-22)$. In a study conducted by Tofiq and Merza (22) in which 45 RA patients and 45 healthy people were compared, IL-17A was found significantly high in RA group. In the same study, no difference was detected in IL-17A levels among groups who received or did not receive biological treatment. No significant elevation was detected in serum IL-17

\section{Table 2. Comparison of rheumatoid arthritis patients with and without osteoporosis}

\begin{tabular}{|c|c|c|c|}
\hline & $\begin{array}{l}\text { RA patients with OP } \\
\text { (group } 1 \text { ) } \\
n=21\end{array}$ & $\begin{array}{l}\text { RA patients without OP } \\
\text { (group } 2 \text { ) } \\
n=22\end{array}$ & p \\
\hline Gender (female, n, \%) & $19(90.5)$ & $17(77.3)$ & 0.41 \\
\hline Age (years, min-max) & $59.0(54.0-65.0)$ & $56.0(43.7-60.7)$ & 0.08 \\
\hline $\mathrm{BMI}\left(\mathrm{kg} / \mathrm{m}^{2}\right.$, mean $\left.\pm \mathrm{SD}\right)$ & $30.5 \pm 6.5$ & $30.5 \pm 6.2$ & 0.98 \\
\hline Smoker (yes, n, \%) & $4(19)$ & $5(22.7)$ & 1.00 \\
\hline Alcohol (yes, n, \%) & $0(0)$ & $0(0)$ & - \\
\hline Fracture (yes, n, \%) & $3(14.3)$ & $1(4.5)$ & 0.35 \\
\hline Age at menopause (years, min-max) & $45.0(43.0-49.0)$ & $50.5(45.5-52.0)$ & 0.012 \\
\hline Lumbar total T score (min-max) & $-2.6[(-3.1)-(-2.5)]$ & $-1.7[(-2.1)-(-0.6)]$ & $<0.001$ \\
\hline Lumbar BMD $\left(\mathrm{g} / \mathrm{cm}^{2}\right.$, mean $\left.\pm \mathrm{SD}\right)$ & $0.74 \pm 0.07$ & $0.91 \pm 0.09$ & $<0.001$ \\
\hline Femoral T score (mean \pm SD) & $-1.98 \pm 0.88$ & $-0.67 \pm 0.62$ & $<0.001$ \\
\hline Femoral BMD $\left(\mathrm{g} / \mathrm{cm}^{2}\right.$, mean $\left.\pm \mathrm{SD}\right)$ & $0.63 \pm 0.09$ & $0.79 \pm 0.08$ & $<0.001$ \\
\hline 25-hydroxy vitamin $\mathrm{D}(\mathrm{ng} / \mathrm{mL}$, mean $\pm \mathrm{SD})$ & $22.74 \pm 5.50$ & $24.09 \pm 11.03$ & 0.62 \\
\hline Parathyroid hormone $(\mathrm{pg} / \mathrm{mL}$, mean $\pm \mathrm{SD})$ & $101.48 \pm 51.77$ & $92.55 \pm 39.29$ & 0.53 \\
\hline Serum calcium (mmol/L, min-max) & $9.4(9.1-9.6)$ & $9.3(8.9-9.4)$ & 0.11 \\
\hline IL-17 (pg/mL, min-max) & 416.3 (396.8-883.9) & $374.9(157.1-430.8)$ & 0.03 \\
\hline Duration of RA (years, min-max) & $10.0(2.5-14.5)$ & $6.0(1.0-10.0)$ & 0.19 \\
\hline Corticosteroid use (n, \%) & $20(95.2)$ & $16(72.7)$ & 0.09 \\
\hline DAS 28 (min-max) & $3.4(2.9-4.5)$ & $3.2(2.4-4.1)$ & 0.08 \\
\hline HAQ score (mean \pm SD) & $0.61 \pm 0.41$ & $0.41 \pm 0.38$ & 0.11 \\
\hline VAS (cm, min-max) & $5(2.0-6.5)$ & $5(1.7-5.0)$ & 0.54 \\
\hline $\mathrm{RF}(\mathrm{U} / \mathrm{mL}$, min-max $)$ & 87.8 (38.0-194.8) & $24.1(3.15-88.7)$ & 0.010 \\
\hline Anti-CCP (min-max) & $126(13.0-200)$ & $31.0(2.2-165.5)$ & 0.090 \\
\hline ESR $(\mathrm{mm} /$ hour, mean $\pm \mathrm{SD})$ & $33.19 \pm 14.38$ & $25.81 \pm 12.59$ & 0.081 \\
\hline $\mathrm{CRP}(\mathrm{mg} / \mathrm{L}$, mean $\pm \mathrm{SD})$ & $10.56 \pm 8.94$ & $7.46 \pm 5.77$ & 0.183 \\
\hline
\end{tabular}


levels in a study conducted by Ziolkowska et al. (23) in which 15 RA patients and eight osteoarthritis patients were compared. IL-17 was detected to be significantly high in synovial fluid of RA patients. As the major source of IL-17, Th-17 cell levels in peripheral blood were not also found different in RA patients in comparison to control groups in other studies $(24,25)$. In our study, we observed that there was no significant difference in IL-17 levels for 43 RA patients and the control group of 42 individuals without RA. Moreover, we discovered that IL-17 levels were not different for 43 RA patients and 20 normal healthy (without RA and OP) volunteers. We examined IL-17 in our study, however, other studies have investigated IL-17A. This might be the reason why IL-17 was not different for RA patients in the current study.

Table 3. Correlation between interleukin-17 level with different variables in patient with rheumatoid arthritis $(n=43)$

\begin{tabular}{|c|c|c|}
\hline & & \\
\hline & $\mathbf{r}$ & $p$ \\
\hline Age & 0.209 & 0.178 \\
\hline Weight & -0.042 & 0.788 \\
\hline Height & -0.149 & 0.339 \\
\hline $\mathrm{BMI}$ & 0.032 & 0.840 \\
\hline Rheumatoid arthritis duration & 0.027 & 0.862 \\
\hline Number of births & -0.154 & 0.371 \\
\hline Menopausal age & -0.112 & 0.548 \\
\hline Lumbar T score & -0.307 & 0.045 \\
\hline Lumbar BMD & -0.298 & 0.052 \\
\hline Femoral T score & -0.293 & 0.057 \\
\hline Femoral BMD & -0.309 & 0.044 \\
\hline DAS 28 & 0.027 & 0.865 \\
\hline Morning stiffness & 0.131 & 0.402 \\
\hline Sensitive joint & 0.198 & 0.204 \\
\hline Swollen joint & -0.048 & 0.762 \\
\hline VAS & 0.031 & 0.844 \\
\hline HAQ & 0.097 & 0.535 \\
\hline ESR & -0.151 & 0.335 \\
\hline CRP & 0.014 & 0.930 \\
\hline RF & 0.063 & 0.689 \\
\hline Anti-CCP & 0.022 & 0.888 \\
\hline 25-hydroxy vitamin D & 0.063 & 0.687 \\
\hline Serum parathyroid hormone & -0.161 & 0.301 \\
\hline Serum calcium & 0.085 & 0.590 \\
\hline Serum phosphorus & 0.047 & 0.766 \\
\hline $\begin{array}{l}\text { Anti-CCP: Anticyclic citrullinated pepti } \\
\text { C-reactive protein, ESR: Eritrosit sedim } \\
\text { questionnaire, RF: Rheumatoid factor, } \\
\text { activity score, IL-17: Interleukin-17, BM } \\
\text { analysis used }\end{array}$ & $\begin{array}{l}\text { Bone mir } \\
\text { ate, } \mathrm{HAQ} \\
\text { al analog } \\
\text { ass index, }\end{array}$ & $\begin{array}{l}\text { density, } \\
\text { Ith assesm } \\
\text { DAS: Dise } \\
\text { on correlat }\end{array}$ \\
\hline
\end{tabular}

In a recent study conducted by Fischer et al. (26) the antiinflammatory activity of combined TNF alpha and IL-17 blockage were researched on human mesenchymal cells. It was detected that blockage of both TNF alpha and IL-17 was more effective than blockage of single cytokine. Both cytokines are influential in bone destruction. TNF alpha and IL-17 have additive and synergic effects for production of IL-6, IL-8, granulocyte colony stimulating factor, and matrix metalloproteinase from fibroblastlike synoviocytes (27). Better results were obtained when bone was remodelled with combined blockage of these cytokines. We excluded RA patients receiving anti-TNF therapy from our study in order to search for only the effect of IL-17 on OP. The major target of RA is skeleton system where bone erosions and generalised OP may develop. OP and associated fracture are important disability causes which result in an impaired quality of life and increase in health expenditures. There are several factors for the development of OP in RA, however, IL-6 and other inflammatory cytokines are considered to be the main reason for OP by impairing OGP/RANK/RANKL system (5). IL-17 has a crucial role for osteoclast formation in autoimmune diseases. The binding of IL-17 to its receptor activates NF-kB and MAPK. IL-17 is required for ACT 1 which is the activator of NF-kB pathway. In studies carried out with RA, it was observed that Th-17 cells not only provide production of RANKL (NF-kB ligand-activated receptor), but also ensure secretion of RANKL by stimulating osteoblasts and induce osteoclast differentiation (14). Likewise, it was shown that IL-17A increased production of RANKL in osteoblasts and decreased OGP production, and therefore, caused osteoclast formation and bone erosion in mouse models of arthritis $(27,28)$.

In a recent prospective study, the correlation between OP and IL-17A levels was analysed. It was detected that serum IL-17A levels were higher in postmenapausal patients with $\mathrm{OP}$, and that there was a negative correlation between IL-17A levels and BMD. Therefore, it was concluded that IL-17A is influential in pathogenesis of postmenopausal OP (29). There are only few studies in which IL-17 levels in patients with OP were evaluated. The existing studies are usually limited to cell cultures and animal models. In a study conducted by Tyagi et al. (30) on ovariectomised rats, it was found that oestrogen insufficiency resulted in an increase in Th-17 cels within bone marrow and an increase in IL-17 levels within peripheral blood. DeSelm et al. (31) showed that deletion in IL-17 RA prevented bone loss. When we compared RA patients without OP, with healthy volunteers in the scope of our study, we observed that there was no significant difference between both groups in terms of IL-17. Based on its role in pathogenesis of RA, we compared IL-17 levels in RA patients with and without OP. We detected a significant elevation in IL-17 levels for RA patients with OP (group 1, n=21) in comparison to RA patients without OP (group 2, $n=22$ ). In line with the study conducted by Molnar et al. (32) we detected a statistically significant negative correlation between IL-17, lumbar spine $\mathrm{T}$ scores, and femoral BMD. No correlation between IL-17 levels and disease activity, 
DAS 28, erythrocyte sedimentation rate, C-reactive protein (CRP) of patients with RA, was detected in a study conducted by Al-Saadany et al. (33). In a study performed by Metawi et al. (16) they found out the positive correlation between IL-17A levels and DAS 28 score, and the number of sensitive joint and number of swollen joints. Likewise, a significant correlation was observed within disease activity and IL-17 levels in a study conducted on 22 RA patients by Melis et al. (19). Yamada et al. (25) could not establish a significant correlation between DAS scores, number of sensitive joints and swollen joint in their study in which 69 RA patients were admitted. Moreover, no significant correlation was detected between serum IL-17 levels, swollen joints, and HAQ in the scope of study performed on 41 RA patients (20). There are also studies in which no significant correlation was established between results of global pain scale (by VAS) and IL-17 levels (20). In this study, although a positive correlation was detected between IL-17 and DAS 28, VAS, HAQ and CRP levels, the results were not statistically significant.

\section{Conclusion}

In this study, no difference was detected between IL-17 levels of patients with and without RA. Likewise, we could not establish a correlation between rheumatoid disease activity and IL-17 levels. However, IL-17 levels of RA patients with OP were significantly elevated in comparison to those patients without OP. The subgroups of IL-17 (such as IL-17A, F, etc) may be more influential in RA pathogenesis. Special attention should be paid to this difference during the studies performed with cytokines, and it will be more convenient to monitor the bone formation and destruction markers.

\section{Ethics}

Ethics Committee Approval: This study was approved by the Adnan Menderes University, Clinical Research Ethics Committee (protocol no: 2015/750).

Informed Consent: Informed consent form was signed for all patients.

Peer-review: Externally peer-reviewed.

\section{Authorship Contributions}

Surgical and Medical Practices: S.A., O.A., G.G., H.Y., Concept: S.A., O.A., G.G., N.S., M.T., Design: S.A., O.A., G.G., H.Y., N.S., Data Collection or Processing: S.A., O.A., G.G., H.Y., N.S., M.T., Analysis or Interpretation: S.A., H.Y., M.T., Literature Search: S.A., O.A., G.G., H.Y., N.S., M.T., Writing: S.A., H.Y., G.G., O.A., N.S., M.T.

Conflict of Interest: No conflict of interest was declared by the authors.

Financial Disclosure: The authors declared that this study received no financial support.

\section{References}

1. Alamanos $Y$, Drosos AA. Epidemiology of adult rheumatoid arthritis. Autoimmun Rev 2005;4:130-6.
2. Orstavik RE, Haugeberg G, Mowinckel P, Høiseth A, Uhlig T, Falch JA, et al. Vertebral deformities in rheumatoid arthritis:a comparison with population-based controls. Arch Intern Med 2004;164:420-5.

3. Forsblad D'Elia H, Larsen A, Waltbrand E, Kvist G, Mellström D, Saxne $T$, et al. Radiographic joint destruction in postmenopausal rheumatoid arthritis is strongly associated with generalised osteoporosis. Ann Rheum Dis 2003;62:617-23.

4. Sinigaglia L, Varenna M, Girasole G, Bianchi G. Epidemiology of osteoporosis in rheumatic diseases. Rheum Dis Clin N Am 2006;32:631-58.

5. Abdel Meguid MH, Hamad YH, Swilam RS, Barakat MS. Relation of interleukin-6 in rheumatoid arthritis patients to systemic bone loss and structural bone damage. Rheumatol Int 2013;33:697-703.

6. Caetano-Lopes J, Rodrigues A, Lopes A, Vale AC, Pitts-Kiefer MA, Vidal B, et al. Rheumatoid Arthritis Bone Fragility Is Associated With Upregulation of IL17 and DKK1 Gene Expression. Clin Rev Allergy Immunol 2014;47:38-45.

7. Hirota $K$, Hashimoto M, Yoshitomi H, Tanaka S, Nomura T, Yamaguchi $T$,et al. T cell self-reactivity forms a cytokine milieu for spontaneous development of IL-17+ Th cells that cause autoimmune arthritis. J Exp Med 2007;204:41-7.

8. Moseley TA, Haudenschild DR, Rose L, Reddi AH. Interleukin-17 family and IL-17 receptors. Cytokine Growth Factor Rev 2003;14:155-74.

9. Witowski J, Ksiazek K, Jorres A. Interleukin-17: a mediator of inflammatory responses. Cell Mol Life Sci 2004;61:567-79.

10. Korn T, Bettelli E, Oukka M, Kuchroo VK. IL-17 and Th17 Cells. Annu Rev Immunol 2009;27:485-517.

11. Lee $Y$. The role of interleukin-17 in bone metabolism and inflammatory skeletal diseases. BMB Rep 2013;46:479-83.

12. Kuestner RE, Taft DW, Haran A, Brandt CS, Brender T, Lum K, et al. Identification of the IL-17 receptor related molecule IL-17RC as the receptor for IL-17F. J Immunol 2007;79:5462-73.

13. Toy D, Kugler D, Wolfson M, Vanden Bos T, Gurgel J, Derry J, et al. Cutting edge: interleukin 17 signals through a heteromeric receptor complex. J Immunol 2006;177:36-9.

14. Li X, Yuan FL, Lu WG, Zhao YQ, Li CW, Li JP, et al. The role of interleukin-17 in mediating joint destruction in rheumatoid arthritis. Biochem Biophys Res Commun 2010;397:131-5.

15. Hwang SY, Kim HY. Expression of IL-17 homologs and their receptors in the synovial cells of rheumatoid arthritis patients. Mol Cells 2005;19:180-4.

16. Metawi SA, Abbas D, Kamal MM, Ibrahim MK. Serum and synovial fluid levels of interleukin-17 in correlation with disease activity in patients with RA. Clin Rheumatol 2011;30:1201-7.

17. Leeb BF, Haindl PM, Maktari A, Nothnagl T, Rintelen B. Diseases activity score- 28 values differ considerably depending on patient's pain perception and sex. J Rheumatol 2007;34:2382-7.

18. Krishman E, Tugwell F, Fries JF. Percentile benchmarks in patients with rheumatoid arthritis: Health Assessment Questionnaire as quality indicator (QI). Arthritis Res Ther 2004;6:505-13.

19. Melis $L$, Vandooren $B$, Kruithof $E$, Jacques $P$, De Vos M, Mielants $\mathrm{H}$, et al. Systemic levels of IL-23 are strongly associated with disease activity in rheumatoid arthritis but not spondyloarthritis. Ann Rheum Dis 2010;69:618-23.

20. Hitchon CA, Alex P, Erdile LB, Frank MB, Dozmorov I, Tang Y, et al. A distinct multicytokine profile is associated with anti-cyclical citrullinated peptide antibodies in patients with early untreated inflammatory arthritis. J Rheumatol 2004;31:2336-46.

21. Kohno $M$, Tsutsumi $A$, Matsui $H$, Sugihara $M$, Suzuki $T$, Mamura $M$, et al. Interleukin-17 gene expression in patients with rheumatoid arthritis. Mod Rheumatol 2008;18:15-22.

22. Tofiq DM, Merza RR. Assessment of the role of IL-17A in rheumatoid arthritis patients; in sulaymaniyah governorate. Eur Sci J 2015;11:358-72.

23. Ziolkowska M, Koc A, Luszczkiewicz G, Ksiezopolska-Pietrzak K, Klimczak E, Chwalinska-Sadowska H, et al. High levels of IL-17 in rheumatoid arthritis patients: IL-15 triggers in vitro IL-17 production via cyclosporin A-sensitive mechanism. J Immunol 2000;164:2832-8.

24. Shahrara S, Huang Q, Mandelin AM, Pope RM. TH-17 cells in rheumatoid arthritis. Arthritis Res Ther 2008;10:93. 
25. Yamada H, Nakashima Y, Okazaki K, Mawatari T, Fukushi Jl, Kaibara N, et al. Th1 but not Th17 cells predominate in the joints of patients with rheumatoid arthritis. Ann Rheum Dis 2008:67:1299-304.

26. Fischer JA, Hueber AJ, Wilson S, Galm M, Baum W, Kitson C, et al. Combined inhibition of tumor necrosis factor $\alpha$ and interleukin-17 as a therapeutic opportunity in rheumatoid arthritis: development and characterization of a novel bispecific antibody. Arthritis Rheumatol 2015:67:51-62.

27. Lubberts $E$, van den Bersselaar L, Oppers-Walgreen B, Schwarzenberger P, Coenen-de Roo CJ, Kolls JK, et al. IL-17 promotes bone erosion in murine collagen-induced arthritis through loss of the receptor activator of NF-kappa B ligand/ osteoprotegerin balance. J Immunol 2003;170:2655-62.

28. Kramer JM, Gaffen SL. Interleukin-17: a new paradigm in inflammation, autoimmunity, and therapy. J Periodontol 2007;78:1083-93
29. Zhang J, Fu Q, Ren Z, Wang Y, Wang C, Shen T, et al. Changes of serum cytokines-related Th1/Th2/Th17 concentration in patients with postmenopausal osteoporosis. Gynecol Endocrinol 2015;31:183-90.

30. Tyagi AM, Srivastava K, Mansoori MN, Trivedi R, Chattopadhyay $\mathrm{N}$, Singh $\mathrm{D}$. Estrogen deficiency induces the differentiation of IL-17 secreting Th17 cells: a new candidate in the pathogenesis of osteoporosis. PLoS One 2012;7:e44552.

31. DeSelm CJ, Takahata Y, Warren J, Chappel JC, Khan T, Li X, et al. IL-17 mediates estrogendeficient osteoporosis in an Act1dependent manner. J Cell Biochem 2012;113:2895-902.

32. Molnar I, Bohaty I, Somogyine-Vari E. High prevalence of increased interleukin-17A serum levels in postmenopausal estrogen deficiency. Menopause 2014;21:749-52.

33. Al-Saadany HM, Hussein MS, Gaber RA, Zaytoun HA. Th-17 cells and serum IL-17 in rheumatoid arthritis patients: Correlation with disease activity and severity. The Egyptian Rheumatologist 2016;38:1-7. 